\title{
Science belongs to no one-and to everyone
}

\author{
Björn L.D.M. Brücher ${ }^{1,2,3, *}$ \\ 1 Theodor-Billroth-Academy ${ }^{\circledR}$, Germany, USA \\ 2 INCORE, International Consortium of Research Excellence of the Theodor-Billroth-Academy ${ }^{\circledR}$, Germany, USA \\ 3 Department of Surgery, Carl-Thiem-Klinikum, Cottbus, Germany
}

Received 27 November 2017, Accepted 1 December 2017

Keywords: Aging, Biotechnology, Cancer, Challenges, Chemistry, Communication, Critical thinking, COPE, CSE, Data, Economy, Ethics, GDP, Healthcare, Health economy, ICMJE, Ignorance, Journal, Life sciences, Mathematics, Medicine, Misconduct, Open access, Physics, Psychology, Publication, Publisher, Predatory, Quality, Research, Responsibility, Science, Social media, Research, Values, WAME

\section{4open}

With this editorial, EDP Sciences launches the new open access (OA), multi- and interdisciplinary journal 4open, which will publish articles from four different disciplines in science and research, including materials and engineering, each with its own Editorial Board. The categories include (1) Life Sciences and Medicine, (2) Chemistry and Applied Chemistry, (3) Physics and Applied Physics, and (4) Mathematics and Applied Mathematics [1]. 4open follows the standards created by the Council of Science Editors (CSE) [2], the World Association of Medical Editors (WAME) [3], the International Committee of Medical Journal Editors (ICMJE) [4], and the committee on publication ethics (COPE) [5]. Major leading societies, academies, and scientists are actively included, as well as promising future young scientists. For the past six years, we have carefully created multiple different concepts, on varied levels and with diverse priorities, which will be shared when the time is ready. Contrary to the mainstream of OA publishing, 4open provides a liberal and fair article processing charge (APC) model [1]. It enables researchers to choose the level of funding they receive, and thus helps to equalize the opportunities and benefits available, by allowing some stipends to flow to researchers in less well-funded fields of science. The peer review process is entirely independent of the APC decision and will in no way alter any decision on scientific merit that the editor should take.

Today, in the twenty-first century, buzz words such as globalization, resource scarcity, rapid technological development, and mass migration are widely used in scientific literature. As is true for most human endeavors, science has power. With power come responsibilities. Good science involves finding helpful solutions to existing

\footnotetext{
*Corresponding author: b-bruecher@gmx .de
}

problems. Great science involves asking questions not immediately answerable and addressing the challenges, which must be proclaimed clearly and openly discussed and debated. Reflection is necessary. Some examples include the following:

- healthcare driven by science as an engine of the broader economy;

- commercialization of science;

- changes in the way certain scientific publications dominate;

- impact as a factor in a publication's reputation;

- indispensable values and tradition;

- non-receptive reading, reflection, and ignorance;

- content by science writers;

- predatory journals;

- social media;

- science belongs to no one - and to everyone.

\section{Healthcare driven by science as an engine of the broader economy}

As the global population increases and ages (Fig. 1) [6], work in geriatric medicine and geriatric science will increase and become common during the next decades. Chronic diseases, which occur mainly in the elderly [7], exact a high cost from society, as DeVol and Bredroussian have shown: "The overall economic impact of absenteeism and presenteeism from common chronic diseases exceeded $\$ 1$ trillion in 2003." [8], reviewed in [9]. In the future, measuring the burden of worldwide healthcare and its economics could focus on a cause-based approach, as opposed to diagnosis and treatment orientated toward symptoms, thus promoting translational research as "the" bridge (Fig. 2). Such a focus would facilitate the personalized and individualized approach in diagnosis and therapy long demanded in oncology [10]. 


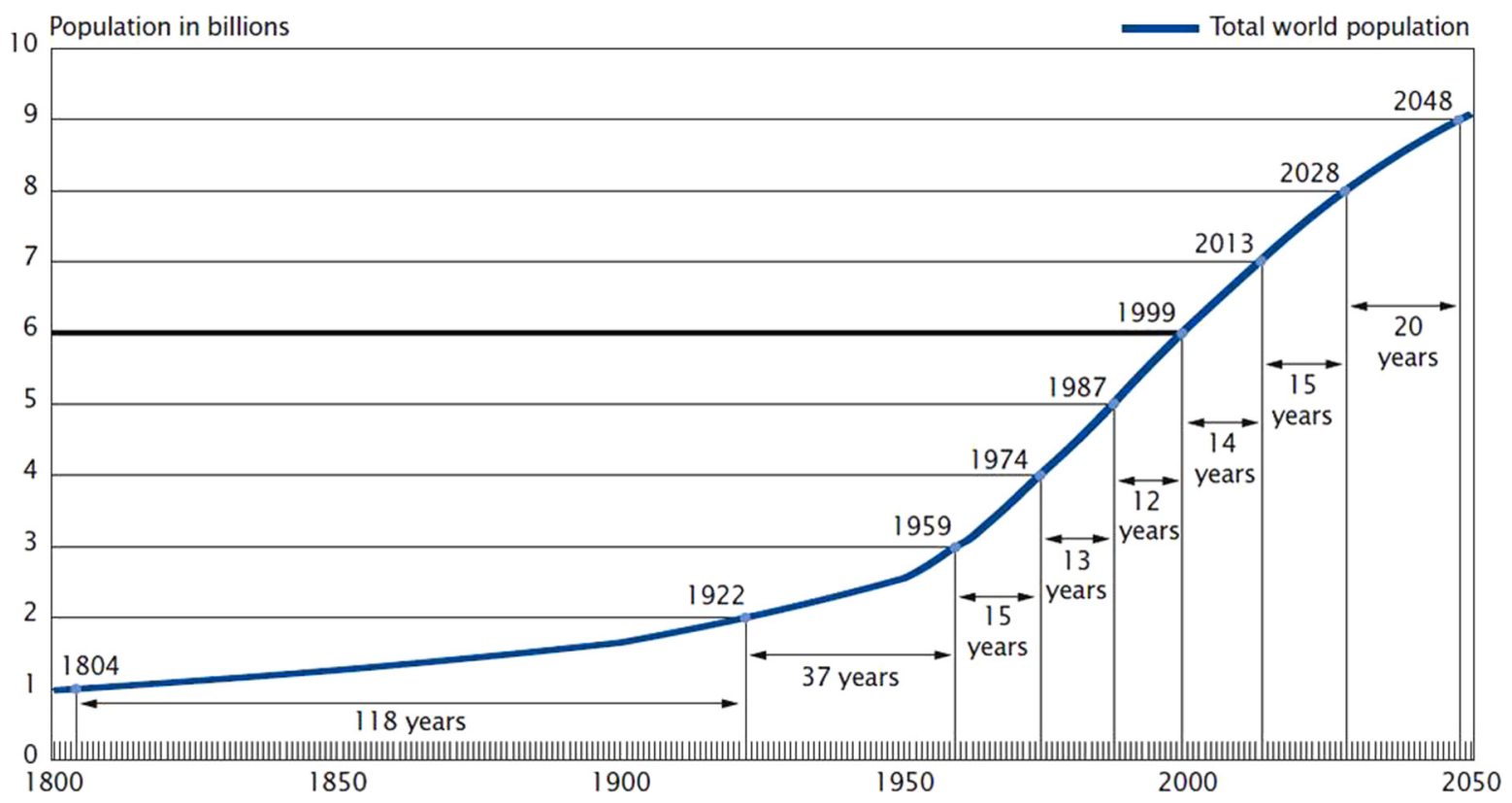

Figure 1. World Population 1800-2050 [6].

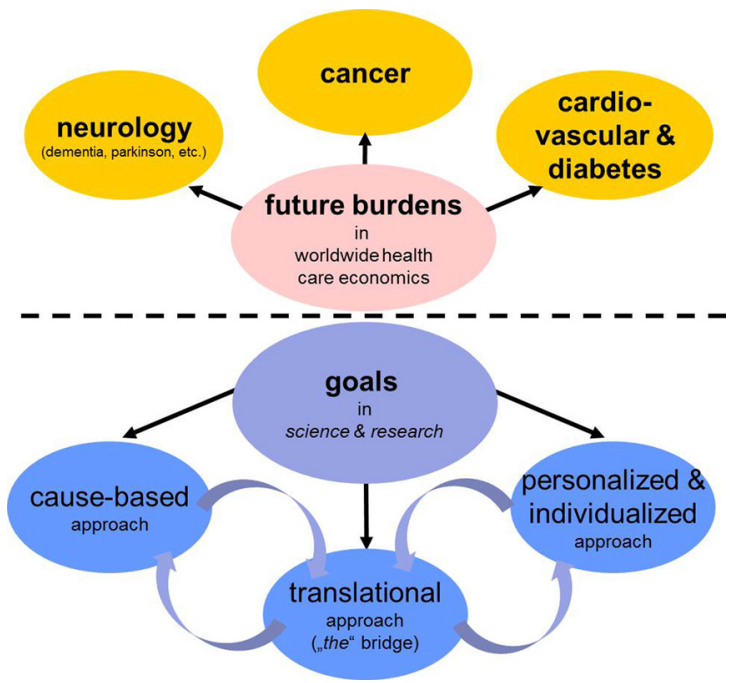

Figure 2. Future burdens in worldwide healthcare economics define goals in science \& research: the need of cause-based research to replace a symptom-orientated approach with translational research as the bridge as the focus shifts to personalized and individualized approach (diagnosis and therapy).

Growth in health economics (HE) partly finances itself $[11,12]$. Improvements in quality in healthcare improve both patient outcome and economic performance. With an optimal healthcare infrastructure, productivity and $\mathrm{HE}$ increase, resulting in a consequent enrichment of the overall economy. Healthcare will be a drag on costs only if improvements in quality and their positive feedback to national and regional economies are restrained. If not ignored, HE serves as a potent driver of economic growth. The percentage that healthcare expenditures comprise of the gross domestic product (GDP) varies by country and state (Fig. 3, Tab. 1) [author's calculation according to [13-16]].

GDP is directly related to improved life expectancy, as has been shown [17], reviewed in [9]. For example, in Germany between 2005 and 2016, an incremental rise in the gross value added (GVA) of investment in research and development from $€ 4.9$ to $€ 8.4$ billion was associated with an increase in industrial output of $+5.4 \%$ and a reduction in $\mathrm{HE}$ of $4.3 \%$ [18]. Although hundreds of variables contribute to the economy of a country, investment in research stands out as important. Countries with less investment in research than Germany, such as Japan and Italy, realized smaller GDP increases [19]. Positive economic effects develop when science leads to improvements in the quality of healthcare, which are reflected in the metrics of patient outcome and overall productivity increase.

National patient registries will be ever more important for healthcare research in the future. The Scandinavian National Healthcare registries were created in Finland in 1969, Denmark in 1977, Sweden in 1987, Iceland in 1999, and Norway in 2008 [20]. These different country-specific patient registries manifest not only advantages, but also have evinced ethical concerns [21]. A paradox for scientists is simultaneous fascination and bafflement as well as depression. Enduring curiosity is needed to find answers and to question the existing paradigms (especially the selfgenerated ones). A Danish patient-cohort study on 445,456 patients revealed, for example, that patients with diverticulitis, when compared to healthy controls, have double the risk of cancer [22], an elevation that could be attributed to chronic inflammation [23]. Resection of the sigmoid, after the second event of sigmoid diverticulitis, eliminates this risk. 


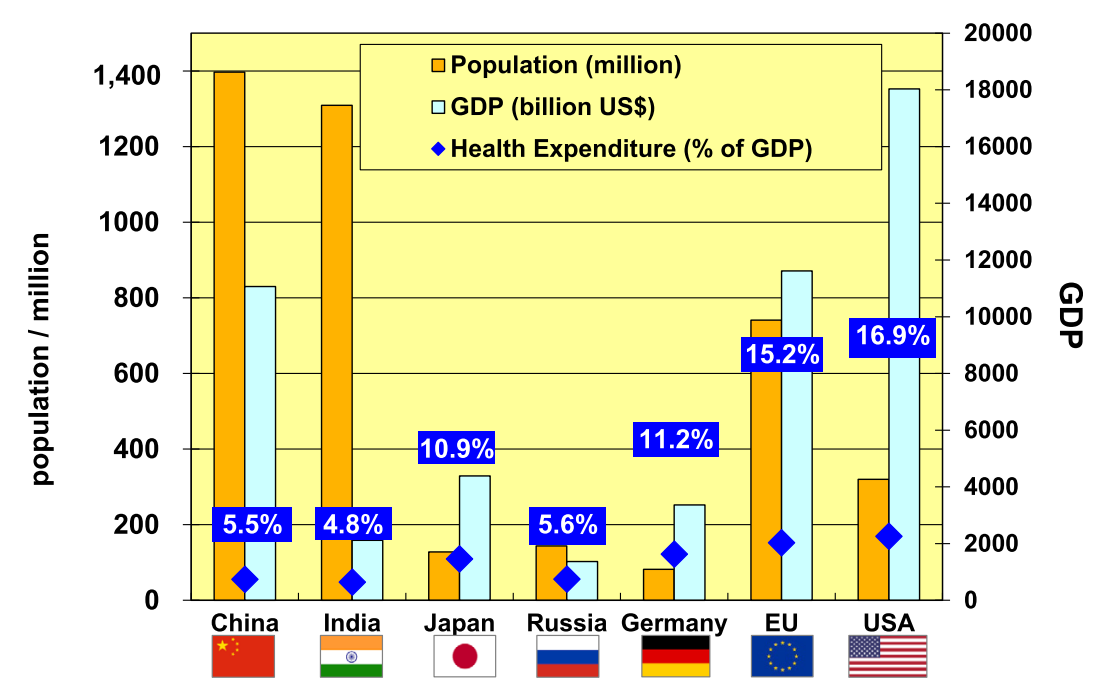

Figure 3. Population, GDP, and percentage health expenditure in various regions, October 2017. Author's calculations [according to [13-16]].

Table 1. Population (million), GDP (billion US\$), GDP per capita, research and development (R\&D) and Health Expenditure (\% of GDP) in China, India, Japan, Russia, Germany, EU and USA, October 2017. Reference: Author's calculations using [according to [13-16]].

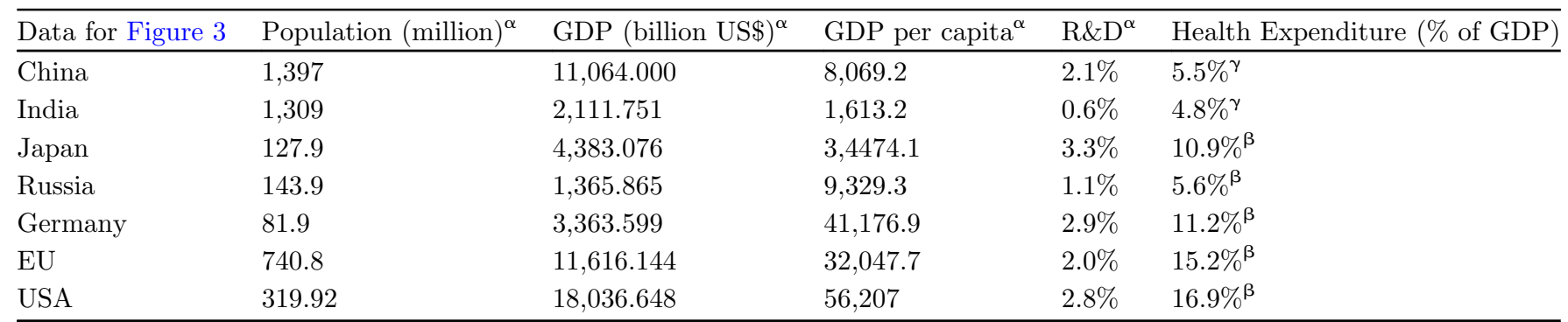

Available 2016 data were incomplete using the sources mentioned below with consequent use of available 2015 data. Original data and graph were transformed for China, India, Japan, Russia, Germany EU and the USA.

${ }^{\alpha}$ Population (million), GDP (billion USD), GDP per capita and R\&D for China, India, Japan, Russia, Germany, EU and USA [according to $[13,14]]$.

${ }^{\beta}$ Health expenditure (\% of GDP) for Japan, Russia, Germany, EU and USA [according to [14,15]].

$\gamma_{2015}$ or 2016 data in regard to health expenditure (\% of GDP) were available for China or India using the resources mentioned. In both, 2014 Health expenditure (\% of GDP) data were available and used.

\section{Commercialization of science}

The burgeoning biotech market has created its own unique selling points in each country and economy. We should try to stay objective about the degenerating biotech hype, as we already live in a time in which nearly every poorly understood disease reflexively is assumed (or even declared) to have originated in genetics. Like a coin with two sides, the large investments in biotech should affect healthcare in the future and, as a consequence, improve the economy. The other side of this coin is the danger of the so-called "businessization" of science, as Pagano has recently pointed out [24]: the increase in the US National Institutes of Health (NIH) budget from US\$ 13.7 billion in 1998 to 27.2 in 2003 paralleled a four-fold increase in the number of doctorates awarded between
1993 and 1997. "One of the major criteria for ranking US biomedical universities is the total amount of their NIH funds." According to the analysis by Rockey, "the total number of these applications has almost doubled - from 25,000 in 1998 to almost 50,000 in 2011" and "the major contributor to the increased demand is a large growth in the number of applicants-from about 19,000 in 1998 to approximately 32,000 in 2011" (blue portion of the bars in Fig. 3 in NIH 2012, not shown) [25].

According to the American Association for the Advancement of Science (AAAS), doctorate programs in the U.S. rose from 8,000 doctoral recipients in 2004 to 12,500 a decade later; but the rate of "postdocs expecting to land a tenure-track faculty position" decreased from greater than $50 \%$ in 2012 to just $21 \%$ recently, a drop that could explain why "the average salary for biology PhDs was 
Table 2. The International Scientific Journal \& Country Ranking (SJR), United States, China, and the European Union (United Kingdom excluded due to Brexit) [according to [33]].

\begin{tabular}{llllll}
\hline Country & Documents & Citable documents & Citations & Self-citations & Citations per document \\
\hline Europe & $11,690,056$ & $10,894,609$ & $208,932,544$ & $42,457,385$ & 374.05 \\
United States & $10,193,964$ & $9,165,271$ & $240,363,880$ & $110,517,058$ & 23.58 \\
China & $4,595,249$ & $4,525,851$ & $32,913,858$ & $18,210,007$ & 7.16 \\
\hline
\end{tabular}

just \$36,000 in their first year of work" [26]. According to the American Institutes for Research (AIR), "61 percent of science, technology, engineering, and math (STEM) PhDs (and 52 percent of biological science PhDs) were working in nonacademic careers in 2010' [27], reviewed in [26]. The global sustainable development priorities 500 years after Martin Luther have been reviewed recently [28]. However, the above numbers by the AAAS and AIR remind us to take greater care with our young scientists, counseling them about their career options and not just defining goals. Postdocs see themselves as cheap workhorses. The scientific community should move to improve working conditions for postdocs. Scientists today are evaluated according to the scale of their funding rather than the quality of their scientific research, a situation that lends credibility to the allegation that science is increasingly carried out as a business, especially since biotechnology has come to be seen as the future driver of healthcare.

Literacy is the most potent tool for tangible and enduring progress. Research leads to benefits for society, informed decision-making, and socio-political changes. An important criticism of open-access publishers and MEGA journals is that, through their emphasis on a business model, they are transforming science to a business endeavor. The British winner of the Fields Medal in mathematics, Sir William Timothy Gowers, is committed to the free exchange of academic knowledge. In 2012, to further his goal, he started a petition drive entitled The Cost of Knowledge to stop support of the Dutch publisher Elsevier [29]. As Germany demands OA, including appropriate pricing, 60 major international science institutions, as well as major academic institutions, have canceled their subscriptions to Elsevier (Jan 1, 2017) $[30,31]$. Against this background, 4open provides a Liberty APC model [1].

\section{Changes in the way certain scientific publications dominate}

Leydesdorff et al. point to the rapid and dynamic growth in China's position in scientific publications compared to Europe and the United States (Fig. 1 in J Informetr 2014, not shown) [32]. Although we assume that China will lead the pack over the next decade, The International Scientific Journal \& Country Ranking (SJR) provides a less robust view, with data that include journaland country-specific scientific indicators obtained from the Scopus ${ }^{\circledR}$ database (Elsevier B.V.) [33]. Table 2 compares the United States, China, and the post-Brexit European Union (EU), using that Scopus data on all the topics listed under the category Life Sciences and Medicine. It shows China well behind the other two entities. The table, however, reveals just one aspect of this data and we should be cautious in our interpretations.

\section{Impact as a factor in a publication's reputation}

History repeats itself: some 50 years ago the increase in scientific publications was referred to as "The present scientific explosion," which "gave rise to more than a proportional publication explosion, which not only reflects the scientific explosion but has its own dynamics and vicious circles" [34]. The foundation of science is trust, which is earned, not given. It takes a long time to build, but it can be lost quickly. The quality and not the quantity determine the reputation of scientists as well as that of journals. Jörg Hacker, President of the German National Academy of Sciences, also known as the Leopoldina, stated in 2011, "The significance of a poet or philosopher cannot be measured by how much he has written" [35]. This quote can serve as a precept for scientific research. Academia and grant-giving organizations often, erroneously, use quantitative measures as indicators of scientific quality. The American Society for Cell Biology (ASCB), together with editors and scientists, initiated in 2013, the San Francisco Declaration on Research Assessment with the intent of improving the evaluation of scientific research beyond the impact factor [36]. The ASCB also asked scientists to sign the declaration [37]. However, the impact factor is simply one variable of many, and it is related more to the prestige of a journal than it is to a criterion of excellence.

\section{Indispensable values and tradition}

Hermann Boerhaave (1668-1738), whose successful teaching made the University of Leyden in Holland one of the leading institutions of the time, was guided by three rules of Hippocrates: (1) use common sense instead of unfounded speculations, (2) observe the patient carefully, and (3) rely upon the healing power of nature [38]. Boerhaave suggested that his student, Gerhard van Swieten (1700-1772), accept a post at the University of Vienna. Van Swieten's work there brought the standards of medical teaching to the highest level and led to the creation of the Vienna Medical School. His efforts 
influenced medical education and research, as well as the practice of medicine, across the globe. The genealogy of many other physicians contributed to the prestige of the School: Anton de Haen (1704-1776), Vinzenz von Kern (1760-1829), Joseph Watmann von Maëlcamp Beaulieu (1789-1866), Johann von Dumreicher (1815-1880), Carl Nicoladoni (1847-1902), Erwin Payr (1871-1946), Martin Kirschner (1879-1942), Rudolf Zenker (1903-1984) and Georg Heberer (1920-1999). Heberer's pupil HansJürgen Peiper (1925) reviewed the tension between tradition and modernity, pointing out that "tradition means passing behavioral patterns, life experiences and basic values" [39], cited by Friedrich Stelzner [40]. Peiper's pupil Jörg Rüdiger Siewert (1940), an advocate of structured interdisciplinary cancer diagnosis and therapy, stated that "discipline borders vanish," emphasized the necessity of multidisciplinary exchange and work, clinically as well as in research [41]. Some 100 years ago, it was Christian Theodor Billroth (1829-1894) who wrote, "Only those who know the past and present of science and art will boost their progress with awareness." In today's circumstances of extreme specialization, coupling tradition with values and interdisciplinary thinking in a multi- and interdisciplinary journal is a logical step. Wolfgang A. Herrmann, President of the Technical University of Munich, alludes to this approach: "Frequently the interesting thing about the interfaces between the classical disciplines is that the disciplinary strengths have to be brought together" [42].

Another example of the success of an interdisciplinary approach lies in the story of Rosalind Franklin (19201959), although sad in terms of ethics and humility. The discovery of the double helix was based, on the one hand, on important findings of Erwin Chargaff (1905-2002) [43], Alfred D. Hershey (1908-1997), and Martha Chase (1927-2003) [44] and, on the other, the X-ray diffraction study of deoxyribonucleic acid (DNA) by Rosalind Franklin and Raymond Gosling (1926-2015) [45]. Franklin's chairman, Maurice Wilkins (1916-2004), secretly showed her X-ray spectrograms with the double helix to James Watson (1928) and Francis Crick (19162004) [46]. Three papers, by Watson and Crick, Wilkins, and Franklin, were published in the same journal and volume $[45,47,48] 64$ years ago, on April 25th, 1953. Rosalind Franklin received no recognition for her contribution. Johann Friedrich Dieffenbach's comment aptly describes the situation: "What is new, acquires friends and enemies, the new is rocking old interests." The consequent discovery of polymerase chain reaction (PCR) in 1955 by Kjell Kleppe (1934-1988) and Moulineux [49] and its important modification by Kary B. Mullis (1944) in 1983 brought about a revolution in biology and science [50].

When we assert that we live in a time of modern science, we should remember that our forebears in science made it possible with their own, earlier developments and achievements [51]. The quote of Isaac Newton still rings true: "If I have seen further, it is by standing on the shoulders of giants."

\section{Non-receptive reading, reflection, and ignorance}

The milestones in human evolution include the following:

- Use of sticks or stones as tools: our ancestors began to use such tools between 3.4 and 2.5 million years ago $[52,53]$.

- Agricultural lifestyle: the change from hunting to agriculture occurred some 12,500 years ago [54].

- The media revolution: mechanical printing appeared in 1450 [55] and quickly became widespread.

- The industrial revolution: repetitive manufacturing began some 250 years ago [56].

- The microprocessor: first manufactured in 1971, it has greatly enhanced our ability to process data and information [57].

- Artificial intelligence (AI) and human perception: research on combining electronic (artificial intelligence or AI) and human perceptions is ongoing, even as we aren't sure what outcome it will have.

An increase in the average intelligence quotient (IQ) during the past 100 years was accompanied by a reduction in cognitive socialization [58]. No real-time medium-e.g. radio, video, smartphone, or other - allows for the necessary steps of reflection, inductive analysis, and critical thinking that the written word does. Seneca's quote, "Humans believe their eyes rather than the ears" (Homines amplius oculis quam auribus credunt) [59] resonates even today. By contrast, in the 20th century we focused on statistically significant correlations, too often misinterpreting these as being causal, rather than associative. The ability to differentiate between the two is based on cogitation. It is not enough to concentrate mainly on words and language - reflection and thinking are needed, as well. It is not mere coincidence that Theodor Billroth stated some hundred years ago, "I cannot understand how someone can read receptively only." How does this happen?

The Latin verb ignorare (to lack knowledge) changed during the 16 th century to the ablaut ignaurus (unknowing/uninformed). Today, ignorance implies that one is unaware of a condition and/or deliberately does not want to deal with it. Thirst for knowledge, according to Cato's quote, "Ne discere cessa" (Do not stop learning), as well as the cultivation and respect of the achievements of our forefathers, might work against ignorance, but the issue seems to be more complex than that. Ignorance can be intentional or accidental; it might be sloppy thinking. Ignorance might become autarkic (self-sufficient) by collective ignorance. The main drawback of our digital century, in which billions of bytes of information are thrust upon us daily, is the difficulty in filtering fact from fiction. The former President of the Deutsche Forschungsgemeinschaft (DFG) and the Max-Planck-Gesellschaft, Hubert Markl (1938-2015), exhibited humility in science: " $A$ caterpillar is by no means a butterfly. When man becomes a real 'man' is only our choice" (Notation: Professor Markl did not mean that his quote be read as misogynous.) [60]. 
Agnotoly, the study of culturally induced ignorance, a term coined by Robert N. Proctor of Stanford [61], is a new discipline that studies how illiteracy is triggered through manipulation, suppression of information, censorship and/or selective cultural policy. We may already live in a time of scientific agnotoly; systematic ignorance could well give way to pseudoscience.

A critical and detailed review of cancer papers of the last 250 years demonstrates that many authors - notable scientists and Nobel laureates among them-who published in "landmark" journals failed to cite the original literature. The dogma that emerged and has persisted for 100 years is the theory that somatic mutation causes the majority of cancers [62]. Among the many possible reasons for the error are incomplete literature researches, receptive reading, or even a purposeful Ignoratio arbitraria. Authors justify omitting citations of the original literature: some claim that scouring the literature for original citations is too time consuming and expensive; some mention that journals limit the number of references in a single paper. However, the fear that the writer himself would shine less brightly could bring out a subliminal opposition to seeking data that would deprecate his own. Some 60 years ago, Bradley wrote "The Tradition of Scientific Critique" on the ideal of scientific medicine in terms of traditional societies [63]. Of course, when writing for publication, it is much easier to cite a recent journal than search for longoutdated papers; but this "citation silence" amounts to a distortion of the available information, and it does not credit the work of earlier generations of scientists.

Although authors must state that their submitted work contains no plagiarism or bias, should we judge papers from decades ago under the rubric of present day pressures? The maxim Ignorantia juris non excusat (ignorance of the law is no excuse) is used more often in law than in science. "Knowing is not enough, we must apply. Willing is not enough; we must do," was coined by Johann Wolfgang von Goethe (1749-1832). Morgan [64], referring to both Van Dalen and Henkins [65] and to Hamilton [66], recognized that writers in the social sciences do not have a rigorous tradition for citation. The lack of a standard that requires writers to include original references penalizes those who attend to the scientific rigor of reading them. Since the quality and validity of social sciences has improved significantly $[67,68]$, the importance of the social sciences on enhancing science \& research should, from my perspective, not be neglected nor be judged by citation tradition alone.

\section{Content by science writers}

Without doubt, excellent science writers work for publishers, newspapers, and media organizations, as already noted $[26,30]$. However, the importance of writers on science who use scientific opinions as the basis for their blogs and provide these as content to social media may be underestimated. Responsible writers on science do not use misleading titles on their blogs or prose solely to attract recognition or "likes." Often, observations that are correctly expressed in a manuscript or scientific work are misinterpreted by readers who do not understand the science or the paper; things get lost in translation. How scientists generate data and statements that are later incorrectly interpreted has been described in a recent paper [62]. To wit, “... scientists searched for DNA mutations in 800 cancer patients (some 200 different cancer types) and compared the tumor DNA with the DNA of healthy cells of the same patients [69]. They reported that mutations found in cancer patients were correctly interpreted in the abstract as associated with the different cancer types, yet the results were misinterpreted in media interviews as though the authors had concluded that such mutations actually caused the cancers" [70]. We consider such posts to be purposeful modifications of the information. Our responsibility as scientists is to insure that the generations that follow us cannot write, "Science and research, especially within biotechnology and molecular biology, promised so much and delivered so little."

\section{Predatory journals}

Many journals have been delisted from major indexing services due to legitimate concerns [71]. Publishers that create large numbers of journals with questionable peer review, and even organize scientific conferences, are termed predatory publishers, journals, or conference organizers. A list of these can be found at the University College Dublin Library [72]. Even authors who tried retracting their own submissions to OMICS International were ignored consistently [73]. In this respect, researchers can thank Jeffrey Beall for his meticulous work and for his list of potential predators, which should be independently verified. When Frontiers was added to that list, Nature and Nature's parent company, Springer Nature, partowners of Frontiers, saw the addition as controversial. Nature is published by The Holtzbrinck Group, Stuttgart, Germany [74]. Later, OMICS Publishing Group, seeking $\$ 1$ billion in damages, sued Beall, and Jeffrey Beall's list was shut down as a result. Scientists around the globe receive daily dozens of advertisements, masked as invitations, to submit their research work, to serve on an editorial board, or to participate in a conference. The invitations come from predatory publishers, and most mention unrealistically short time limits for submitting. These demonstrate how the predators use the "invitation" to hide their marketing pitch.

We do not know how many scientists are taken in by these predatory practices. Even when a scientist withdraws her name or retracts a manuscript and asks to be removed from the mailing lists, the practices continue [73]. Meanwhile, predators are a threat to the integrity of scientific research [75]. Since the first decade of this new century, the OA publishing industry has exploded; active predatory publishing increased by some $400 \%$ within just four years (Fig. 4) [76]. Predators have darkened legitimate scientific research by attempting to blur the line between authentic and questionable science. They are "the dark dangerous force" of publishing. The number of predatory 


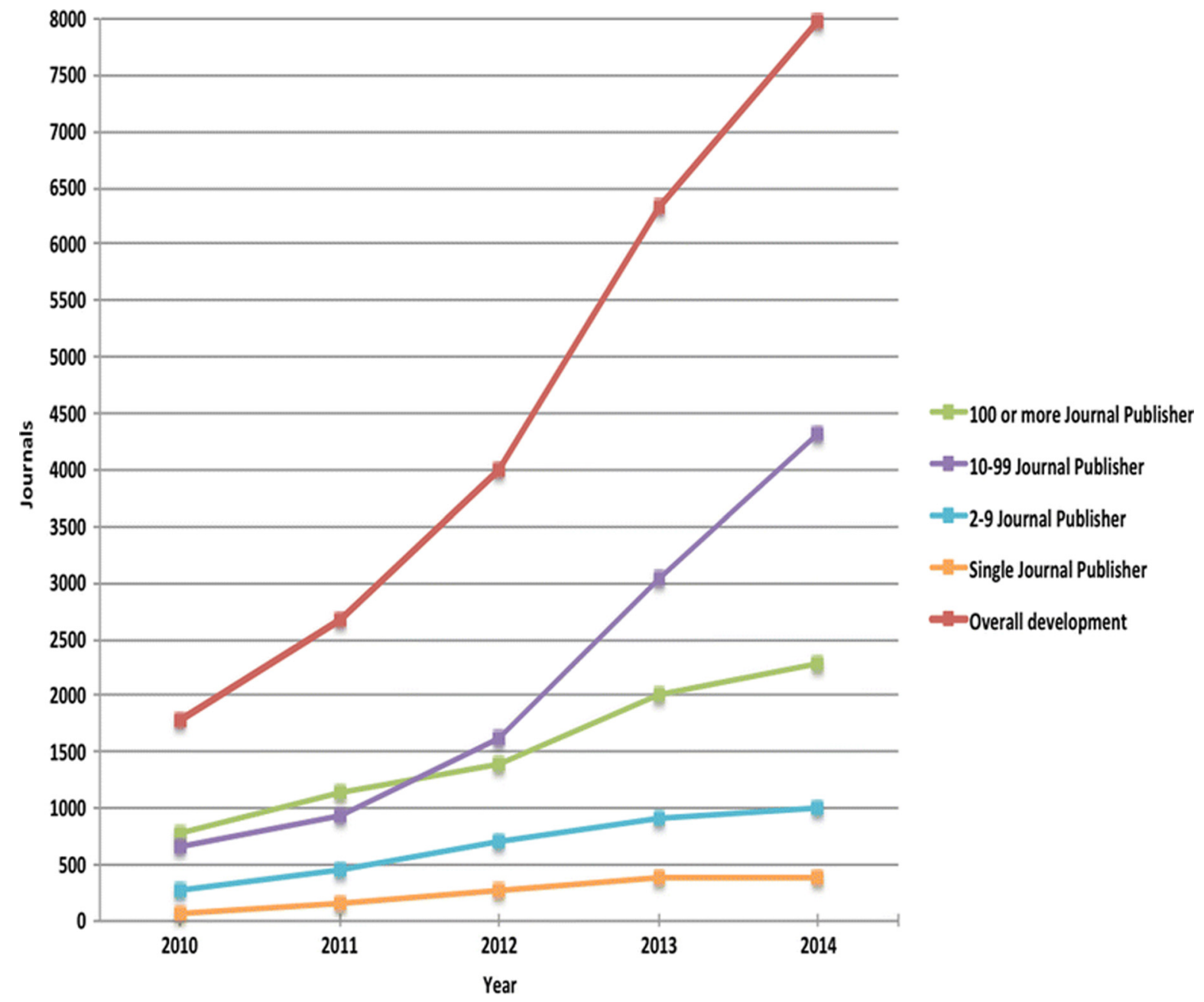

Figure 4. Active predator OA journals, 2010-2014 [76].

journals proves that an increase in the number of published papers does not reflect an increase in scientific quality. Even leading journals and publishers have been slow to react - at first, silence was the norm. 4open will require a clause in the conflict statement of interest that either no tie exists between an author and a predator publication or service, or that any previous tie has been dissolved.

\section{Silence is not an option}

Silence in the face of predatory publishers, journals, and conference organizers is not an option. Stelzner pointed out that, "New knowledge is a venture. Misunderstanding and competition are the rule: Silentium livoris (the silence of envy) was used in antiquity" and "The truth is not always the probability. Anyone who agrees to a new, real knowledge loses his recognition. Silence is much safer" [40]. Editorial teams acutely aware of predatory journals can take all the steps necessary to ensure that integrity is at the forefront of their own journal's ethos. As well, journals will adhere to the standards disseminated by the CSE [2], WAME [3], ICMJE [4], and COPE [5], which cover the responsibilities of authors, editors, and peer reviewers throughout the publishing workflow.

\section{Long-term impact of predatory activities}

These predatory activities engender mistrust among scientists and between the lay public toward science and toward all publishers - including those with integrity and serious writers from the broader media. Scientists should consider it a duty to build trust with the lay public. They have always raised their voices; they should choose their language wisely. We live in a decade of inflation in scientific publishing. We cannot blame a layman for not separating fiction and reality, for not distinguishing the signal and the noise, for the line between them is increasingly blurred. Inflation, a sustained increase in prices that reflects a loss in the value of currency, usually ends when the bubble bursts. We, as scientists, can be grateful for the non-profit COPE, which serves to define best practices in the ethics of publishing. Human societies are structured by internal regulations that reflect laws, ethics, and morals. Scientific societies must be responsible for the corollary internal oversight. From my personal perspective, Retraction Watch - a blog created by editors investigating and reporting on retractions in scientific papers - serves as the necessary, transparent answer, placing scientific integrity for the researchers, the journals 
in which they publish, and their respective publishers at the top where it belongs [77]. Since 1975, retraction rates in the life science and biomedical scientific publications have increased tenfold due to errors $(21.7 \%)$, misconduct $(67 \%)$, fraud or suspected fraud $(43.4 \%)$, duplicate publication (14.2\%), and plagiarism (9.8\%) [78]. The authors considered the numbers underestimated, as "not all articles suspected of fraud have been retracted," e.g. by Lancet or the British Medical Journal. Humans err; these data demonstrate that anyone, even the reviewer and the editorial board of the most highly ranked journals, can fail. Even so, we should not use Bertrand Russell's (1872-1970) words as an excuse: "Even if all experts are of an opinion, they may well be in error."

We must beware of the contrary aspect of our caution: a scientist falsely accused of scientific misconduct can suffer enormous personal and scientific consequences; a denunciation can destroy his reputation, integrity, and even his employment. According to Publius Vergilius Maro (70 BC-19 BC) "The rumor grows as it goes" (Fama crescit eundo) [79]. A statement that "the scientist was completely rehabilitated" is insufficient if his career had been shattered. Caution is a wise advisor, especially when our power to limit the immediate spread of reports is null.

\section{Social media}

Expecting to carry on an objective, transparent discussion in social media would be truly utopian. Social media information is driven by opinion more than fact, and "alternative" truths are commonly expressed. Twitter, in 280 characters per tweet, is incapable of presenting differing, but correct, observations. What one posts may, in the process of condensation, be altered completely. Some of our most powerful leaders ignore scientific evidence. Mankind was not and is not free from evil, and neither is society nor science. We may remind ourselves that social media reflect society as well as science, but the risk of spreading the denigration of the dissenters is great. The communication scientist Lutz M. Hagen and his co-authors reported in 2017 how the U.S. social psychologist Leon Festinger's (1919-1989) 1957 theory of cognitive dissonance [80] could, in accordance with Donsbach and Mothes [81], explain the empirically confirmed phenomenon that people prefer to perceive and recall such information as conforms to their preexisting attitudes, that adjustments are stabilized at the individual level [82]. The phenomenon clarifies the way polarizing effects are enhanced by the blogs and messages that appear continually in social networks. The dissemination of "loud posts" through social media is dangerous to science.

\section{Science belongs to no one - and to everyone}

Professor Martin Stratmann, President of the Max Planck Society, stated "We need to create an efficient and widely budget-neutral transition which offers fresh incentives to traditional publishers to cooperate and transfer established journals to Open Access". OA publishing will for sure increase, and major leading societies, such as the Max Planck Society, will take advantage of this opportunity: "The world's research organizations, together with their libraries, need to act jointly and with some coordination, with the key aim of shifting the money out of the subscription system and so that it can be re-invested in open access" [83]. In 2015, more than $80 \%$ of the total article output by the Max Planck Society was published in journals from 20 key publishers, while 5 of these 20 publishers were already pure OA publishers; the Max Planck Society already defined its goal for 2010, that "none of our 20 key publishers continues to operate on a regular subscription scheme" [84].

As previously noted, science must be founded on ethics and values, and it must stand for building bridges - not walls. Mankind is not free from evil, and neither is science. Some of the experiences pointed out above - even meanwhile ruled as questionable developments - might be helpful for the scientific community to re-direct the boat of science.

Scientists face some challenging developments-we should take advantage of them as an opportunity to forge ahead with truth in research and publishing. Although science belongs to no one - and to everyone, property (science) obliges. It is up to us - every single one of us in science and research - to ensure that Gustave Le Bon's "psychology of the crowd" does not become a self-fulfilling condition [85]. Otherwise, we scientists should not be counted as Homo sapiens in the original translation of the term.

\section{Acknowledgements}

I greatly acknowledge my thanks for valuable discussions with Ijaz S. Jamall, Klaus Ammann, Marjan S. Rupnik, Masaharu Seno, Martin Hodson, Hartmut Kühn, Gary Wnek, Robert Eibl, Boris Pasche, Pentti Nieminen, Francisco Solano, Biswapriya B. Misra, Anastasios Koulaouzidis, Volkmar Weissig, Marjan Slak Rupnik, George Anogianakis, Vladimir Matveev, Ronald M. Przygodzki, Robert Eibl, Carmen Escobedo Lucea, Steingrimur Stefansson, and Ray Perkins, as well as the members of the Editorial Board of 4open and the web group of the Theodor-Billroth-Academyß on LinkedIn. The ongoing exchange for the last nearly 10 years has been important to my thinking. I thank each one. Figure 3 with its Table 1 was created by the author in 2013 for China, Japan, Bavaria, Virginia, United Kingdom, Germany and the USA. Due to the welcome advice of Professor George Anogianakis, Thessaloniki, Greece and Dr. Claus Roll, I was able to actualize the data as well as the graph. The manuscript was supported by the

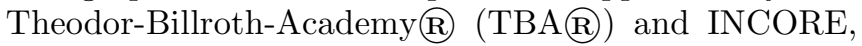
(International Consortium of Research Excellence) of the $(\mathrm{TBA} \cap)$. 


\section{Conflict of interest}

The author reports the following conflict of interest: $\mathrm{He}$ is Editor-in-Chief in Life Sciences-Medicine of 4open by EDP Sciences. He is affiliated with the Theodor-BillrothAcademy ${ }^{\circledR}\left(\right.$ TBA $\left.^{\circledR}\right)$ and its INCORE. The author alone is responsible for the content and writing of this paper.

\section{Nomenclature}

$\begin{array}{ll}\text { ASCB } & \text { American Society for Cell Biology } \\ \text { APC } & \text { Article Processing Charge } \\ \text { AIR } & \text { American Institutes for Research } \\ \text { BC } & \text { Before Christ } \\ \text { COPE } & \text { Committee on Publication Ethics } \\ \text { CSE } & \text { Council of Science Editors } \\ \text { DFG } & \text { Deutsche Forschungsgemeinschaft } \\ \text { DNA } & \text { Deoxyribonucleic acid } \\ \text { EU } & \text { European Union } \\ \text { GDP } & \text { Gross domestic product } \\ \text { GVA } & \text { Gross value added } \\ \text { HE } & \text { Health economics } \\ \text { ICMJE } & \text { International Committee of Medical Journal } \\ & \text { Editors }\end{array}$

INCORE International Consortium of Research Excellence of the TBA ${ }^{\circledR}$

IQ Intelligence quotient

NIH US National Institutes of Health

OA Open Access

PCR Polymerase chain reaction

SJR SCImago Journal Rank, a metric used by Elsevier

STEM Science, technology, engineering, and mathematics

TBA Theodor-Billroth-Academy ${ }^{\circledR}\left(\right.$ TBA $\left.^{\circledR}\right)$

WAME World Association of Medical Editors

\section{References}

1. 4open website (2017), https://www.4open-sciences.org

2. Council of Science Editors (CSE) (2017), https://www. councilscienceeditors.org/

3. World Association of Medical Editors (WAME) (2017), http://www.wame.org/

4. International Committee of Medical Journal Editors (ICMJE) (2017), http://www.icmje.org/

5. Committee on Publication Ethics (COPE) (2017), https:// publicationethics.org/

6. U.S. Census Bureau (2004), International population reports $\mathrm{WP} / 02$, global population profile: 2002, US Government Printing Office, Washington, D.C. https:// www.census.gov/prod/2004pubs/wp-02.pdf

7. He W, Goodkind D, Kowal P (U.S. Census Bureau) (2015/ 2016), International population reports, P95/16-1, an aging world: 2015, US Government Publishing Office, Washington, D.C. https://www.census.gov/library/publications/ 2016/demo/P95-16-1.html

8. DeVol R, Bedroussian A (2007), An unhealthy America: the economic burden of chronic disease, The Milkin Institute, Santa Monica, CA. http://www.milkeninstitute.org/publi cations/view/321
9. Mirvis DM, Chang CF, Cosby A (2008), Health as an economic engine: evidence for the importance of health in economic development. J Health Hum Serv Adm 31, 30-57. https://www.ncbi.nlm.nih.gov/pubmed/18575147

10. Brücher BLDM, Lyman G, van Hillegersberg R, Pollock RE, Lordick F, Yang HK, Ushijima T, Yeoh KG, Skricka T, Polkowski W, Wallner G, Verwaal V, Garofalo A, D'Ugo D, Roviello F, Steinau HU, Wallace TJ, Daumer M, Maihle N, Reid III TJ, Ducreux M, Kitagawa Y, Knuth A, Zilberstein B, Steele SR, Jamall IS (2014), Imagine a world without cancer. BMC Cancer 14, 1-8. https://bmccancer.biomed central.com/articles/10.1186/1471-2407-14-186

11. Schneider M, Karmann A, Braeseke G (2014), Produktivität der Gesundheitswirtschaft - Gutachten für das Bundesministerium für Wirtschaft und Technologie. Gabler Verlag. Springer Fachmedien Wiesbaden. DOI:10.1007/978-3-65806045-9. http://www.springer.com/de/book/9783658060442

12. Schneider M (2016), Gesundheitswirtschaftliche Gesamtrechnung 2000-2014 - Gutachten für das Bundesministerium für Wirtschaft und Energie. Herausgeber: Dr. Markus Schneider, Dr. Dennis A. Ostwald, Prof. Dr. Alexander Karmann, Prof. Dr. Klaus-Dirk Henke, Dr. Grit Braeseke, et al., 378 Seiten. ISBN 978-3-8487-2785-8. https://www. zvab.com/products/isbn/9783848727858?cm sp=bdp- $\quad-9$ 783848727858- -isbn10

13. Worldometers, http://www.worldometers.info/, access October 28, 2017

14. Data bank by the World Bank (2017), www.databank. worldofbank.org, access October 28, 2017.

15. Statistics by the Organisation for Economic Co-operation and Development (OECD) (2017), www.stats.oecd.org, access October 28, 2017.

16. Eurostat statistics by the European Union (2017), http://ec. europa.eu/eurostat/statistics-explained/index.php/Govern ment_expenditure_on_health, access October 28, 2017.

17. Preston S (1975), The changing relation between mortality and the level of economic development. Popul Stud 29, 231238. https://academic.oup.com/ije/article-lookup/doi/ 10.1093/ije/dym075

18. Gesundheitswirtschaft: Fakten und Zahlen Ausgabe (2016), Datenbasis: Statistisches Bundesamt; Berechnung und Darstellung, WifOR/BASYS. http://www.bmwi.de/Redak tion/DE/Publikationen/Wirtschaft/gesundheitswirtsch aft-fakten-zahlen-2016.pdf? blob=publicationFile\&v $=12$

19. Belitz H, Junker S, Schiersch A, Podstawski A (2015), Wirkung von Forschung und Wachstum auf das Wirtschaftswachstum. Gutachten des DIW Berlins im Auftrag der KfW Bankengruppe, Berlin, 16. Juni 2015. https:// www.kfw.de/PDF/Download-Center/Konzernthemen/Re search/PDF-Dokumente-Studien-und-Materialien/Gutach ten_FuE_DIW_KfW_internet.pdf

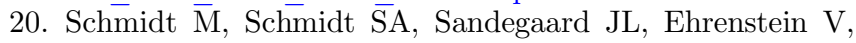
Pedersen L, Sørensen HT (2015), The Danish national patient registry: a review of content, data quality, and research potential. Clin Epidemiol 7, 449-490. https://www. dovepress.com/the-danish-national-patient-registry-a-re view-of-content-data-quality-peer-reviewed-article-CLEP

21. Ludvigsson JF, Håberg SE, Knudsen GP, Lafolie P, Zoega H, Sarkkola C, von Kraemer S, Weiderpass E, Nørgaard M (2015), Ethical aspects of registry-based research in the Nordic countries. Clin Epidemiol 7, 491-508. https: / /www. dovepress.com/ethical-aspects-of-registry-based-researchin-the-nordic-countries-peer-reviewed-article-CLEP

22. Mortensen LQ, Burcharth J, Andresen K, Pommergaard HC, Rosenberg J (2017), An 18-year nationwide cohort study on the association between diverticulitis and colon cancer. Ann Surg 265, 954-959. https://www.ncbi.nlm.nih. gov/pubmed/27192351 
23. Brücher BLDM, Jamall JS (2014), Epistemology of the origin of cancer: a new paradigm. BMC Cancer 14, 1-15. https://bmccancer.biomedcentral.com/articles/10.1186/ 1471-2407-14-331

24. Pagano M (2017), Don't run biomedical science as a business. Nature 547, 381. https://www.nature.com/ news/don-t-run-biomedical-science-as-a-business-1.22366

25. Rockey S (2012), Rock talk: more applications; many more applicants, National Institutes of Health (NIH). Retrieved August 9, 2012. https://nexus.od.nih.gov/all/2012/08/09/ more-applications-many-more-applicants/

26. Offord C (2017), Addressing biomedical science's PhD problem. Scientist. January 1, 2017. http://www.thescientist.com/?articles.view/articleNo/47732/title/Addres sing-Biomedical-Science-s-PhD-Problem/

27. Turk-Bicakci L, Berger A, Haxton C (2014), The nonacademic careers of STEM PhD holders, American Institutes for Research 2014. April 1, 2014. http://www.air.org/ resource/nonacademic-careers-stem-ph-d-holders

28. Lutz W (2017), Global sustainable development priorities 500 y after Luther: Sola schola et sanitate. Proc Natl Acad Sci USA 114, 6904-6913. DOI:10.1073/pnas.1702609114. Epub 2017 June 19. http://www.pnas.org/content/114/ 27/6904.short

29. The Cost of Knowledge, http://thecostofknowledge.com/

30. Doctorow C (2016), Germany-wide consortium of research libraries announce boycott of Elsevier journals over open access. Boing Boing. Retrieved December 27, 2016. https: / boingboing. net/2016/12/15/germany-wide-consortium-of-res.html

31. Kwon D (2017), Major German universities cancel Elsevier contracts. Scientist, July 17, 2017. http://www.the-scien tist.com/?articles.view/articleNo/49906/title/Major-Ger man-Universities-Cancel-Elsevier-Contracts/

32. Leydesdorff L, Wagner CS, Bornmann L (2014), The European Union, China, and the United States in the top$1 \%$ and top- $10 \%$ layers of most-frequently cited publications: competition and collaborations. J Informetr 8, 606617. https://arxiv.org/abs/1404.0462

33. International Scientific Journal \& Country Ranking (SJR) (2017), http://www.scimagojr.com/index.php. Used July $27,2017$.

34. Margolis J (1967), Citation indexing and evaluation of scientific papers. Science 155, 1213-1219. https://www. ncbi.nlm.nih.gov/pubmed/5335153

35. Hacker J (2011) Begrüßung und Würdigung der LeopoldinaAusgabe anlässlich der Festveranstaltung. - Goethe - Die Schriften zur Naturwissenschaft. 04.11.2012 in LeopoldinaJahrbuch, 393-399 (2012). http://www.leopoldina.org/ fileadmin/redaktion/Mitglieder/Praesident/2011-11-04_F estansprache_Goetheausgabe.pdf

36. Hoppeler H (2013), San Francisco declaration on research assessment. J Exp Biol 216, 2163-2164. http://jeb.biolo gists.org/content/216/12/2163

37. (2012), Signing the San Francisco declaration of research assessment. http://www.ascb.org/dora/

38. Vogl A (1967), Six hundred years of medicine in Vienna. A history of the Vienna School of Medicine. Bull N Y Acad Med 43, 282-299. https://www.ncbi.nlm.nih.gov/pmc/ articles/PMC1806589/

39. Peiper HJ (2005), Chirurgische Tradition, chirurgische Schule - haben Sie Bestand? Chirurg 76, 1086-1090. https://link.springer.com/content/pdf/10.1007/s00104005-1112-0.pdf

40. Stelzner F (2012), Die Macht und Ohnmacht des Schweigens. Festvortrag bei der Jahresveranstaltung der Sudetendeutschen Akademie der Wissenschaften und Künste, Munich, Germany, 19. Oktober 2012 http://www.sudeten deutsche-akademie.eu/Festvortrag2012.pdf
41. Siewert JR (2010), Disappearing borders between disciplines: recognize developments, benefit from common interests. Chirurg 81, 1057. https://link.springer.com/ article/10.1007/s00104-010-1959-6

42. Brack G (2015), TU Präsident Wolfgang A. Herrmann. BR24. (02.10.2015) October 2, 2015. http://www.br.de/ nachrichten/oberbayern/inhalt/wolfgang-herrmann-portr aet-100.html

43. Chargaff E, Zamenhof S (1948), Human desoxypentose nucleic acid: composition of human desoxypentose nucleic acid. J Biol Chem 173, 327. https://www.ncbi.nlm.nih.gov/ pubmed $/$ ?term $=\mathrm{J}+\mathrm{Biol}+\mathrm{Chem}+1948 \% 3 \mathrm{~B}+173 \% 3 \mathrm{~A}+327$

44. Hershey JG, Chase M (1952), Independent functions of viral protein and nucleic acid in growth of bacteriophage. J Gen Physiol 36, 39-56. https://www.ncbi.nlm.nih.gov/pubmed/ 12981234

45. Franklin RE, Gosling R (1953), Molecular configuration in sodium thymonucleate. Nature 171, 740-741. https://www. ncbi.nlm.nih.gov/pubmed/13054694

46. Balchin J (2003), Quantensprünge:100 große Wissenschaftler und ihre Ideen. (Rosalind Franklin). Gondrom, Bindlach. http://isbnplus.ru/Quantenspr\%C3\%BCnge-100-gro $\% \mathrm{C} 3 \% 9 \mathrm{Fe}-$ Wissenschaftler-und-ihre-Ideen-cJon-Balchin/ $9 /$ dccddjj

47. Watson JD, Crick FH (1953), Molecular structure of nucleic acids: a structure for deoxyribose nucleic acid. Nature 171, 737-738. https://www.ncbi.nlm.nih.gov/pubmed/13054692

48. Wilkins MHF, Stokes AR, Wilson HR (1953), Molecular structure of deoxypentose nucleic acids. Nature 171, 738740. https://www.ncbi.nlm.nih.gov/pubmed/13054693

49. Kleppe K, Ohtsuka E, Kleppe R, Molineux I, Khorana HG (1971), Studies on polynucleotides. XCVI. Repair replications of short synthetic DNA's as catalyzed by DNA polymerases. J Mol Biol 56, 341-361. https://www.ncbi. nlm.nih.gov/pubmed/4927950

50. Mullis K, Faloona F, Scharf S, Saiki R, Horn G, Erlich H (1986), Specific enzymatic amplification of DNA in vitro: the polymerase chain reaction. Cold Spring Harb Symp Quant Biol 51, 263-273. https://www.ncbi.nlm.nih.gov/ pubmed $/ 3472723$

51. Iaccarino M (2003), Science and culture. EMBO Rep 4, 220223. http://onlinelibrary.wiley.com/doi/10.1038/sj.embor. embor781/abstract

52. Semaw S, Rogers MJ, Quade J, Renne PR, Butler RF, Dominguez-Rodrigo M, Stout D, Hart WS, Pickering T, Simpson SW (2003), 2.6-Million-year-old stone tools and associated bones from OGS-6 and OGS-7, Gona, Afar, Ethiopia. J Hum Evol 45, 169-177. https://www.ncbi.nlm. nih.gov/pubmed/14529651

53. McPherron SP, Alemseged Z, Marean CW, Wynn JG, Reed D, Geraads D, Bobe R, Béarat HA (2010), Evidence for stone-tool-assisted consumption of animal tissues before 3.39 million years ago at Dikika, Ethiopia. Nature 466, 857860. https://www.ncbi.nlm.nih.gov/pubmed/20703305

54. Barker G (2009), The agricultural revolution in prehistory: Why did foragers become farmers? Oxford University Press. ISBN 978-0-19-955995-4. https://global.oup.com/academ ic/product/the-agricultural-revolution-in-prehistory$9780199559954 ? \mathrm{cc}=$ de\&lang $=$ en \&

55. Füssel S (2012), Die Ausbreitung des Buchdrucks in Deutschland und durch deutsche Drucker in Europa (ca. 1454-1470), in: Mobilità dei mestieri del libro tra Quattrocento e Seicento : convegno internazionale, Roma, Hrsg.: Santoro, Marco. - Pisa [u.a.], 2013. - (Biblioteca di "Paratesto"; 8), 14-16 marzo 2012 S. 55-76. http://opac. regestaimperii.de/lang_de/anzeige.php?buchbeitrag=Die 
+ Ausbreitung + des + Buchdrucks + in + Deutschland + und + durch + deutsche + Drucker + in + Europa $+\% 28$ ca. $+1454-$ $1470 \% 29 \& \mathrm{pk}=1871974$

56. Kiely R (1998), Industrialization and development: a comparative analysis, UCL Press, London. http://www.worldcat.org/ title/industrialization-and-development-a-comparative-analy sis/oclc/932373843?referer $=$ di\&ht=edition

57. The New York Times Guide to Essential Knowledge (2011), A desk reference for the curious mind. St. Martin's Press, 1376 pages. ISBN-10: 0312643020. https://www.abebooks. de/9780312643027/New-York-Times-Guide-Essential$0312643020 / \mathrm{plp}$

58. Greenfield PC (2009), Technology and informal education: What is taught - What is learned? Science 323, 69-71. http://greenfieldlab.psych.ucla.edu/Media_Studies files/Greenfield\%202009.pdf

59. Lucius Annaeus Seneca: Epistulae morales. https://books. google.de/books?id $=$ kj1wqwQ81UC\&printsec $=$ frontcov er\&dq $=$ Lucius + Annaeus + Seneca: + Epistulae + morales $\& h$ $l=$ de\&sa $=$ X\&ved $=0$ ahUKEwi11rn63K7VAhVIYlAKHTxk CWcQ6AEIPTAD $\# \mathrm{v}=$ onepage\&q=Lucius\%20Annaeus $\%$ 20Seneca\%3A\%20Epistulae\%20morales\&f=false or http:/ www.thelatinlibrary.com/sen/seneca.ep1.shtml

60. Markl H (2001), Eine Raupe ist noch lange kein Schmetterling. Wann der Mensch zum wirklichen Menschen" wird, ist allein unsere Entscheidung. 27. November 2001 in: Frankfurter Allgemeine Zeitung FAZ 2001, Feuilleton, S. 49. https://fazarchiv.faz.net/fazSearch/index/searchForm?q= Hubert + Markl\&search in=\&timePeriod=timeFilter\&ti meFilter $=\& D T$ from $=\& D T$ to $=\& \mathrm{KO} \% 2 \mathrm{CSO}=\&$ crxd efs $=\& \mathrm{NN}=\& \mathrm{CO} \overline{\%} 2 \mathrm{C} 1 \mathrm{E}=\& \mathrm{CN}=\& \mathrm{BC}=\&$ maxHits $=\&$ sorting $=$ date asc\&toggleFilter $=\&$ dosearch $=$ y\&offset $=170 \#$ hitlist

61. Proctor RN (1995), Cancer wars: how politics shapes what we know and don't know about cancer, BasicBooks, New York. https://www.amazon.com/Cancer-Wars-PoliticsShapes-About/dp/0465008593

62. Brücher BLDM, Jamall JS (2016), Somatic mutation theory - Why it's wrong for most cancers. Cell Physiol Biochem 38, 1663-1680. https://www.karger.com/?DOI=10.1159/000443106

63. Bradley SE (1957), The tradition of scientific critique. J Clin Invest 36, 866-868. http://www.jci.org/articles/view/103494

64. Morgan SP, Lynch SM (2001), Success and future of demography: the role of data and methods. Ann N Y Acad Sci 954, 35-51. https://www.ncbi.nlm.nih.gov/pubmed/11797864

65. Van Dalen HP, Henkins K (1999), How influential are demography journals? Pop Devel Rev 25, 229-251. https:// www.nidi.nl/shared/content/output/1999/pdr-25-02-van dalen.pdf

66. Hamilton DP (1991) Research paper: who's uncited now? Science 251, 25. http://garfield.library.upenn.edu/papers hamilton2.html

67. Rivera JA, Sotres-Alvarez D, Habicht JP, Shamah T, Villalpando S (2004), Impact of the Mexican program for education, health, and nutrition (Progresa) on rates of growth and anemia in infants and young children: a randomized effectiveness study. JAMA 291, 2563-2570.

68. Bastow S, Dunleavy P, Tinkler J (2014), The impact of the social sciences: how academics and their research make a difference, in: S Bastow, P Dunleavy, J Tinkler (Eds.), Sage, London. ISBN: 978-1-4462-7510-8.

69. Weinhold N, Jacobsen A, Schultz N, Sander C, Lee W (2014), Genome-wide analysis of noncoding regulatory mutations in cancer. Nat Genet 46, 1160-1165. https:// www.ncbi.nlm.nih.gov/pubmed/25261935
70. ScienceNordic Interview (2014) by Kristian Sjøgren with the authors of Reference 37. http://sciencenordic.com/

71. (2017) Multiple OMICS journals delisted from major index over concerns - Retraction watch at retraction watch. http://retractionwatch.com/2017/03/27/multiple-omicsjournals-delisted-major-index-concerns /

72. (2017) Scholarly communications: predatory publishers \& conferences. http://libguides.ucd.ie/publishing/predatory

73. Vaucher P (2013), Can I trust OMICS publishing group? ResearchGate November 26, 2013. https://www.research gate.net/post/Can_I_trust_OMICS_publishing_group

74. Silver A (2017), Controversial website that lists 'predatory' publishers shuts down. Nature. https://www.nature.com/ news/controversial-website-that-lists-predatory-publish ers-shuts-down-1.21328

75. Johal J, Ward R, Gielecki J, Walocha J, Natsis K, Tubbs RS, Loukas M (2017), Beware of the predatory science journal: a potential threat to the integrity of medical research. Clin Anat, July 6, 2017. DOI:10.1002/ca.22899. [Epub ahead of print]. https://www.ncbi.nlm.nih.gov/pubmed/28509358

76. Shen C, Björk BC (2015), Predatory' open access: a longitudinal study of article volumes and market characteristics. BMC Med 13, 230. https://bmcmedicine.biomedcen tral.com/articles/10.1186/s12916-015-0469-2

77. (2017) Retraction Watch. http://retractionwatch.com/

78. Fang FC, Steen RG, Casadevall A (2012), Misconduct accounts for the majority of retracted scientific publications. Proc Natl Acad Sci USA 109, 17028-17033. DOI:10.1073/ pnas.1212247109.

79. Publius Vergilius Maro: Aeneis, IV, 174-177: "Fama, malum qua non aliud velocius ullum: mobilitate viget virisque adquirit eundo, parva metu primo, mox sese attollit in auras ingrediturque solo et caput inter nubila condit".

80. Festinger L (1957), A theory of cognitive dissonance, Stanford University. ISBN 9780804709118. http://www. sup.org/books/title/?id $=3850$

81. Donsbach W, Mothes C (2012), The dissonant self: contributions from dissonance theory to a new agenda in studying political communication, in: C Salmone (Ed.), Communication yearbook 36, Routledge, New York, pp. 3-44. http://www. tandfonline.com/doi/abs/10.1080/23808985.2013.11679124

82. Hagen LM, Au AM, Wieland M (2017), Polarisierung im Social Web und der intervenierende Effekt von Bildung. Eine Untersuchung zu den Folgen algorithmischer Medien am Beispiel der Zustimmung zu Merkels "Wir schaffen das!". kommunikation@gesellschaft, 18,1-20.http://www.ssoar. info/ssoar/handle/document/51503

83. Schimmer R, Geschuhn KK, Vogler A (2015), Disrupting the subscription journals' business model for the necessary large-scale transformation to open access. DOI:10.17617/ 1.3. http://pubman.mpdl.mpg.de/pubman/item/esci doc:2148961:7/component/escidoc:2149096/MPDL OATransition White Paper.pdf

84. Schimmer $\bar{R}$, Overkamp I (2017), Horizonte jenseits des Monopols der Verlagsplattformen. Talk presented at XL. Bibliothekstagung der Max-Planck-Gesellschaft, Berlin. 2017-04-03-2017-04-05. http://pubman.mpdl.mpg.de/pub man/item/escidoc:2451425:1/component/esci doc:2451424/oa_bt17_jenseitsVerlagsmono pol 20170403.pdff

85. Le $\bar{B}$ on G (1895), Psychologie des foules. éd. Félix Alcan. https://electrodes.files.wordpress.com/2008/12/psychologie _des_foules__gustave_lebon_le_bon_gallica_ed_1895. $\overline{\mathrm{pdf}}$ 